\title{
EFFECT OF PARTIAL SUBSTITUTION OF A COMMERCIAL CONCENTRATE FEED MIXTURE CRUDE PROTEIN BY HYDROPONIC BARLEY FODDER IN DIETS OF APRI RABBITS ON: 2- GROWTH PERFORMANCE, SLAUGHTER AND CARCASS TRAITS, MEAT COMPOSITION AND ECONOMIC EFFICIENCY
}

\author{
AA. Gabr, A.Z. Mehrez, M.Y. EL-Ayek and Alla M. Gad \\ Department of Animal Production, Faculty of Agriculture, Mansoura University, Egypt \\ Corresponding author:ahmedagabr@yahoo.com
}

Received: $2 / 9 / 2019$

Accepted: 24/10/2019

\section{SUMMARY}

This study was conducted to investigate the influence of partial substitution of concentrate feed mixture (CFM) diet by hydroponic sprouted barley grains in diets of growing APRI rabbits on their productive performance and carcass traits. A total number of 40 male weaned rabbits at 6 weeks of age, were used in four tested groups (10 rabbits each) during feeding period from 6 to 12 weeks of age. Rabbits in the $1^{\text {st }}$ group were fed concentrate feed mixture (CFM) served as control (D1). While, in the ${ }^{2 n d}, 3^{\text {rd }}$ and $4^{\text {th }}$ groups, 20,40 and $60 \%$ of CFM-Crude protein (CP) was replaced by hydroponic barley grains $(H B-C P)$ and will be referred to as $D 2$, $D 3$ and D4 diets, respectively. The main results indicated that group fed DIhad the highest significant values $(P<0.05)$ of average total and daily gain, relative growth rate $(\%)$, performance index, compared with those fed $H B$ diets. The lowest significant values for previous parameter $(P<0.05)$ were recorded for D4. The percentage of dressing, liver, lung and the relative weight of intestine did not significantly differ among tested groups. Feeding HB diets caused improving in CP content and reducing EE content of rabbit meat, compared with control group. The highest value of economic efficiency of feeding (\%) (E.E.F) was recoded in D1 followed by $D 3$ then D2, while the lowest value was recorded in D4.

Keywords: Hydroponic barley, sprouting barley, APRI rabbits, productive performance, economical efficiency and carcass traits

\section{INTRODUCTION}

In most of Middle East countries, traditional green fodder production cannot easily be increased because of many constraints such as: increasing human pressure on land for production of cereal grains, oil seeds and pulses, decreasing land size for fodder cultivation, climatic condition change, lack of water or saline water, non-availability of same quality green fodder or good quality fodder seeds throughout the year, more growth time (approx. 4560 days), seasonal cataclysm, fertilizer requirement and high cost of fertilization (MOA, 2014; Gebremedhin et al., 2015 and Saidi and Abo Omar, 2015).So, Hydroponics is now emerging as an alternative technology to grow fodder for human and different farm animals (Naik et al., 2011; Naiket al., 2012 and Naik et al., 2013). In addition, hydroponic growing is privileges of free soil, chemical fertilizers, free of herbicides and pesticides and producing 10 times the amount of conventional fodder as a traditional farming (Kide et al., 2015). Moreover, hydroponically grown green fodder is highly water efficient and reduces water waste and essential natural and man-made resources required to grow fodder while controlling the effects of climate and growing conditions (Anonymous, 2015).It is important to mention that studies simultaneously hydroponic grown forage as livestock feed, especially in rabbits need more studies. Therefore, the main objectives of the current study were to determine the influence of partial substitution of commercial concentrate diet by hydroponic sprouted barley in diets of growing APRI rabbits on their productive performance, economical efficiency and carcass traits.

\section{MATERIALS AND METHODS}

This experiment was conducted in a private rabbit farm at Mansoura City of Al-Dakahlia Governorate, Egypt, during the period from March to April, 2017.

A total number of 40 Animal Production Research Institute (APRI) weaned male rabbits with 6 weeks of age, were used in a complete randomized design of four experimental groups (10 rabbits each) during feeding period from 6 to 12 weeks. Rabbits in the $1^{\text {st }}$ group were fed commercial rabbit diet served as control (concentrate feed mixture "CFM", D1). While, in the $2^{\text {nd }}, 3^{\text {rd }}$ and $4^{\text {th }}$ groups, 20, 40 and $60 \%$ of CFM-CP was replaced by hydroponic barley (HB$\mathrm{CP}$ ) and will be referred to as D2, D3 and D4, respectively. The CFM contained wheat bran (22), soy bean meal, $44 \%$ (20), alfa alfa (20\%), caraway straw (15\%), yellow corn (5), barley grains (15), limestone $(1 \%)$, common salt $(0.30 \%)$, vit. \&min. Premix $(0.30 \%)$, di-calcium phosphate $(1.25 \%)$, antitoxin $(0.10 \%)$ and anti-cococidia $(0.05 \%)$. The $1^{\text {st }}$ part

Issued by The Egyptian Society of Animal Production 
of present study concerning the impact of tested diets on the calculated chemical composition of the tested diets, nutrients digestibility, feeding value, blood constituents and caecum activity have been published by Mehrez et al. (2018). The four tested diets contained $16.0 \% \mathrm{CP}$. Rabbits in all groups were fed to cover their requirements according to NRC (1977) and Cheeke (1987). The rabbits were housed in galvanized wire cages $(44 \mathrm{~cm}$ width $\times 35 \mathrm{~cm}$ height $\times 53 \mathrm{~cm}$ depth) and fresh water automatic nipple drinker at all time. All rabbits were kept under the same managerial, hygienic and environmental conditions. The CFM meal was offered at 8 a.m. while the hydroponic barley (HB) fodder was given at 5 p.m. (Table 1).

Table 1. Proximate chemical analysis (\%)of tested feed ingredients and the calculated composition of the tested diets (on DM \% basis)

\begin{tabular}{|c|c|c|c|c|}
\hline \multirow[t]{2}{*}{ Item } & \multicolumn{4}{|c|}{ Feed ingredients } \\
\hline & \multicolumn{2}{|c|}{ HB } & \multicolumn{2}{|c|}{ CFM } \\
\hline $\mathrm{DM}$ & \multicolumn{2}{|c|}{15.0} & \multicolumn{2}{|c|}{91.3} \\
\hline $\mathrm{OM}$ & \multicolumn{2}{|c|}{96.3} & \multicolumn{2}{|c|}{85.1} \\
\hline $\mathrm{EE}$ & \multicolumn{2}{|c|}{3.04} & \multicolumn{2}{|c|}{2.77} \\
\hline $\mathrm{CP}$ & \multicolumn{2}{|c|}{16.0} & \multicolumn{2}{|c|}{16.0} \\
\hline $\mathrm{CF}$ & \multicolumn{2}{|c|}{14.5} & \multicolumn{2}{|c|}{12.4} \\
\hline NFE & \multicolumn{2}{|c|}{62.8} & \multicolumn{2}{|c|}{53.9} \\
\hline Ash & \multicolumn{2}{|c|}{3.70} & \multicolumn{2}{|c|}{14.9} \\
\hline \multicolumn{5}{|c|}{ Experimental diets: } \\
\hline Item & D1 & D2 & D3 & D4 \\
\hline DM & 91.3 & 82.0 & 75.4 & 67.3 \\
\hline $\mathrm{OM}$ & 85.2 & 86.5 & 87.4 & 88.6 \\
\hline EE & 2.80 & 2.80 & 2.80 & 2.80 \\
\hline $\mathrm{CP}$ & 16.0 & 16.0 & 16.0 & 16.0 \\
\hline $\mathrm{CF}$ & 12.4 & 12.4 & 12.8 & 13.1 \\
\hline NFE & 54.0 & 55.3 & 55.8 & 56.7 \\
\hline Ash & 14.9 & 13.5 & 12.6 & 11.4 \\
\hline
\end{tabular}

\section{Hydroponic system and grain sprouting:}

As described previously by Mehrez et al. (2018) hydroponic barley (Hordeum vulgare L.) was sprouted in a temperature controlled room. The temperature was maintained at $24^{\circ} \mathrm{C}$ and continuous lighting was also provided throughout the 7day growing period. A sprinkler with a timer control device was used to achieve the set interval and running time indicated above. An air conditioner was used to control temperature inside the growth chamber which was maintained at $24^{\circ} \mathrm{C} \pm 1{ }^{\circ} \mathrm{C}$. The relative humidity in the growth room was $54 \%$.

\section{Rabbit's growth performance:}

Live body weight and feed intake were recorded weekly throughout the experimental feeding period. Then, body weight gain, feed conversion ratio and performance index were evaluated as indices of growth performance. Feed conversion ratio (FCR) was calculated as the amount of feed consumed per unit of BWG as follows:

FCR

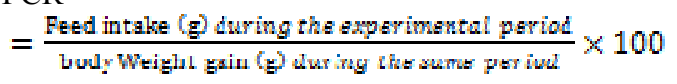

Performance index (PI) was calculated as live body weight $(\mathrm{kg})$ times 100 divided by feed conversion ratio as follows:

$$
\mathrm{PI}=\frac{\text { firal Live body waight }(\mathrm{Hg})}{\text { Feed conwergion }} \times 100
$$

Slaughter and carcass traits:

At the end of the experiment, three representative rabbits from each treatment were chosen and slaughtered after fasting for 12 hours. They were individually weighed and slaughtered. After estimating fasting live body weight at slaughter (LBW), rabbits were carefully sacrificed, skinned and emptied. Fur weight was recorded after skinning the rabbits. Weights of hot carcass ( $\mathrm{HCW}$, eviscerated carcass including head), liver (LW), heart (HW), kidneys (KW) and lungs (LW) were individually recorded. The total edible parts were calculated as HCW plus total giblets (i.e. the sum of liver, heart and kidneys). Relative weights of $\mathrm{HCW}$, liver, heart, kidneys were calculated. Mortality rate (MR) was calculated as follows:

MR $-\frac{\text { Number of animals diet }}{\text { Totalnumber of animal at start }} \times 100$

\section{Chemical analysis for meat:}

Meat samples were taken from the same side of the rabbits femur. Meat samples were chemically analyzed at the Animal Nutrition laboratory. The A.O.A.C (1990) official methods were applied for the conventional nutritive analysis using triplicate samples of $3-5 \mathrm{~g}$ and in order to obtain consistent results. The following regression equation (Mertinet al., 2012) was used to calculate energy value of meet: Energy value $(\mathrm{kJ} .100 \mathrm{~g}-1)=(16.75 \mathrm{x}$ total content of proteins $)+(37.68 \times$ total Fat content $)$.

\section{Statistical analysis:}

Data of the present study were statistically examined by using complete randomized design according to SAS (2003). Duncan's Multiple Range 
Test (Duncan, 1955) was performed to detect the significant differences among means.

\section{RESULTS AND DISCUSSION}

Average total and daily gain (ATG) (g):

As shown in Table (2) the ATG and ADG values recorded for control (D1) group were significantly higher than those fed HB diets, while, D2 and D3 showed no significant difference between them. The lowest significant values of ATG and ADG were recorded for D4.In this field, Shanti et al. (2017) found that replacing pelleted commercial feed by wet HB had negative effects on rabbits' performance. Similar trend has been reported by Ahour (2001) with growing rabbits. These results agree with those reported by Morales et al. (2009) who found that body weight linearly decreased by $0.20 \pm 0.040 \mathrm{~g} / \mathrm{d}(\mathrm{P}<0.001)$ per unit of hydroponic green barley forage (HGBF) increased with growing New Zealand rabbits.

\section{Relative growth rate ( $R G R)$ :}

Relative growth rate (RGR) of rabbits for different treatment groups are presented in Table (2). During the whole period $(6-12 \mathrm{wks})$ the highest significant value was shown with rabbits fed D1, followed by those fed D2 without significant difference between them. However, there were no significant differences between groups fed D2 and D3 diets in this respect. While, the lowest significant value was recorded in rabbits fed D4, compared with the other dietary treatments.

Table 2. Effect of dietary treatments on average daily and total gain (g), relative growth rate performance (\%), feed intake and feed conversion ratio of growing APRI rabbits from 6 to 12 weeks of age

\begin{tabular}{|c|c|c|c|c|c|}
\hline \multirow{2}{*}{ Parameters } & \multicolumn{4}{|c|}{ Experimental diets } & \multirow[t]{2}{*}{ \pm SEM } \\
\hline & D1 & D2 & D3 & D4 & \\
\hline No. of rabbits at $6 \mathrm{wk}$ & 10 & 10 & 10 & 10 & -------- \\
\hline Final no. of rabbits at $12 \mathrm{wk}$ & 10 & 10 & 10 & 9 & ------- \\
\hline Initial live body weight (LBW) (g) & 838.5 & 838.0 & 838.5 & 837.5 & 20.29 \\
\hline Final $(\mathrm{LBW})(\mathrm{g})$ : & $1885.0^{\mathrm{a}}$ & $1760.0^{\mathrm{b}}$ & $1697.5^{b}$ & $1393.3^{c}$ & 44.97 \\
\hline Average total gain ( $\mathrm{g}$ ) & $1046.5^{\mathrm{a}}$ & $922.0^{\mathrm{b}}$ & $859.0^{\mathrm{b}}$ & $555.8^{\mathrm{c}}$ & 41.64 \\
\hline Average daily gain $(\mathrm{g})$ & $24.92^{\mathrm{a}}$ & $21.95^{\mathrm{b}}$ & $20.45^{b}$ & $13.23^{\mathrm{c}}$ & 0.991 \\
\hline \multicolumn{6}{|c|}{ Average dry matter intake (ADMI) $(\mathrm{g} / \mathrm{d})($ during $6: 12 \mathrm{wk})$ : } \\
\hline From CFM & $93.00^{\mathrm{a}}$ & $65.18^{\mathrm{b}}$ & $56.50^{\mathrm{b}}$ & $41.43^{\mathrm{c}}$ & 3.62 \\
\hline From HB & $0.00^{\mathrm{c}}$ & $16.29^{\mathrm{b}}$ & $16.26^{\mathrm{b}}$ & $22.05^{\mathrm{a}}$ & 1.33 \\
\hline Total ADMI (g/h/d) & $93.00^{\mathrm{a}}$ & $81.64^{\mathrm{b}}$ & $73.20^{\mathrm{cb}}$ & $63.41^{\mathrm{c}}$ & 4.15 \\
\hline $\operatorname{ADMI}\left(\mathrm{g} / \mathrm{Kg} \mathrm{BW} \mathrm{W}^{0.75}\right)$ & $41.49^{\mathrm{a}}$ & $37.65^{\mathrm{ab}}$ & $34.45^{\mathrm{b}}$ & $32.85^{\mathrm{b}}$ & 1.74 \\
\hline \multicolumn{6}{|c|}{ Feed conversion ratio (g ADMI/g daily gain) : } \\
\hline $\begin{array}{l}\text { Feed conversion ratio (g ADMI/g daily } \\
\text { gain) ) } 6: 12 \mathrm{wk}\end{array}$ & $3.70^{\mathrm{b}}$ & $3.74^{\mathrm{b}}$ & $3.64^{b}$ & $4.87^{\mathrm{a}}$ & 0.20 \\
\hline Relative growth rate $(\%)$ & $76.73^{\mathrm{a}}$ & $70.91^{\mathrm{ab}}$ & $67.83^{b}$ & $50.96^{\mathrm{c}}$ & 2.53 \\
\hline Performance index $(\%)$ & $50.95^{\mathrm{a}}$ & $47.06^{\mathrm{a}}$ & $46.63^{\mathrm{a}}$ & $28.61^{\mathrm{b}}$ & 2.44 \\
\hline Mortality (\%) & 0 & 0 & 0 & 10 & -- \\
\hline Diarrheal cases $(\%)$ & 0 & 10 & 20 & 44 & -- \\
\hline
\end{tabular}

$\mathrm{a} \& \mathrm{~b}$ and $\mathrm{c}$ : means in the same row with different superscripts differ significantly $(\mathrm{P}<0.05)$.

\section{Feed conversion ratio (FCR):}

According to the statistical analysis of data in Table (2), concerning the feed conversion ratio (FCR), it was obvious that the worst significant $(\mathrm{P}<0.05)$ value was recorded with group fed $\mathrm{D} 4$, while no significant differences among other dietary treatments (D1, D2 and D3) were noted. However, rabbits fed D3 showed the best value of FCR (3.64\%) followed by those fed D1 (without HB) $(3.70 \%)$ and those fed D2 (3.74\%). Rabbits fed D4 had the worst value $(4.87 \%)$ of FCR. Such negative effect on FCR resulted from replacing $\mathrm{HB}$ at the high level $(60 \%)$ in D4 could be attributed to the lowest ADMI (63.41 $\mathrm{g} / \mathrm{d})$ as well as ADG (13.23 g/d). This could mean that D4 did not cover the need of rabbit's requirements from energy and protein to support their animal performance compared with those containing (20 and $40 \%$ of HB) (Table 2). The normal FCR obtained with other tested dietary treatments could support this idea. Similar trend as that observed herein has been found by Shanti et al. (2017) who reported that the poor performance observed in rabbits fed the highest level of $\mathrm{HB}(60 \mathrm{HB})$ could be explained by the deficit of $\mathrm{DE}$ and crude protein intake.

\section{Performance index (PI):}

Regarding performance index (PI), it's worthy to noting that the best PI value have been recorded for group fed D1 $(50.95 \%)$ followed by group fed D2 $(47.06 \%)$ and those fed D3 (46.63\%) without significant differences among them have been observed. While, the lowest significant $(\mathrm{P}<0.05)$ value has been recorded with those fed D4 (28.61 \%).In this respect, Mohsen et al. (2015) reported that no significant difference among dietary treatments on PI was recorded during the whole experimental period ( 8 to 16 wk) with growing New Zealand White (NZW) rabbits fed HB diets. However, one rabbit died from group fed D4 and this may be as a 
result of diarrhea which was considerably higher in group 4 (44\%) which represent about 2.2 and $4.4 \%$ of that in group fed D3 and D2, respectively or due to pathogenic bacteria or both.

\section{Effect of dietary treatments on carcass characteristics:}

Data concerning the carcass characteristics of the growing APRI rabbits are presented in Table (3). It is interesting to note that pre-slaughter LBW and weights of carcass yield were not significantly affected $(\mathrm{P}>0.05)$ by feeding rabbits on $\mathrm{HB}$ diets. However, there was significant difference $(\mathrm{P}<0.05)$ between control and treatment diets, since the heaviest value of pre-slaughter LBW and weights of carcass yield (2.162 and $1.987 \mathrm{~kg}$, respectively) were recorded with D1diet, while group fed D4 showed the lowest value (1.507 and $1.458 \mathrm{Kg}$, respectively). The percentage of dressing, liver, lung and the relative weight of intestine did not significantly differ among tested groups. The weight of hot carcass was significantly $(\mathrm{P}<0.05)$ affected by using $\mathrm{HB}$, being the heaviest in rabbits fed D1 (1132 g) then rabbits fed D3 and D2 (870 and $835 \mathrm{~g}$, respectively), while the lowest value was that of rabbits fed D4 (727 g). These results are in line with the findings of Morales et al. (2009) who found that dressing percentage of rabbits was not affected by replacing a commercial feed with hydroponic green barley forage. In addition, replacement up to $50 \%$ of the commercial concentrate diet with hydroponic green oats forage did not significantly affect $(\mathrm{P}<0.05)$ the slaughter weight and dressing out percent of Californian rabbits (Carmona et al., 2011). Forage supplementation had no significant influence on carcass productivity of rabbits (Moussa et al., 2014). Similarly, AbouSekkenet al. (2012) also revealed that caecum length was significantly longer $(\mathrm{P}<0.05)$ for rabbits fed all diets treated with sprouted grains than control.

Table 3. Effect of dietary treatments on carcass characteristics of growing APRI rabbits at 12 weeks of age

\begin{tabular}{|c|c|c|c|c|c|}
\hline \multirow[t]{2}{*}{ Item } & \multicolumn{4}{|c|}{ Experimental diets } & \multirow{2}{*}{$\pm \mathrm{SEN}$} \\
\hline & D1 & D2 & D3 & D4 & \\
\hline Pre-slaughter LBW, kg & $2.162^{\mathrm{a}}$ & $1.6233^{b}$ & $1.6733^{b}$ & $1.507^{b}$ & 0.104 \\
\hline Carcass, kg & $1.987^{\mathrm{a}}$ & $1.568^{\mathrm{b}}$ & $1.610^{\mathrm{b}}$ & $1.458^{\mathrm{b}}$ & 0.061 \\
\hline *Dressing, \% & 52.95 & 51.42 & 52.09 & 48.25 & 0.114 \\
\hline Hot carcass, $\mathrm{g}$ & $1132^{\mathrm{a}}$ & $835^{\mathrm{b}}$ & $870^{\mathrm{b}}$ & $727^{c}$ & 23.33 \\
\hline \multicolumn{6}{|c|}{ Organ \% } \\
\hline Head, \% & $0.011^{\mathrm{c}}$ & $0.014^{\mathrm{a}}$ & $0.013^{b}$ & $0.0103^{b}$ & 0.004 \\
\hline Liver, \% & 7.606 & 6.728 & 6.236 & 6.414 & 0.485 \\
\hline Kidneys, \% & $1.111^{\mathrm{b}}$ & $1.523^{\mathrm{a}}$ & $1.442^{\mathrm{a}}$ & $1.464^{\mathrm{a}}$ & 0.043 \\
\hline Heart, \% & $0.720^{\mathrm{a}}$ & $0.408^{\mathrm{c}}$ & $0.629^{\mathrm{ab}}$ & $0.504^{\mathrm{bc}}$ & 0.043 \\
\hline Lungs, \% & 1.688 & 1.654 & 1.527 & 1.474 & 0.064 \\
\hline Intestine, $\mathbf{g}$ & 80.73 & 67.47 & 64.30 & 61.03 & 7.100 \\
\hline Intestine length, $\mathrm{cm}$ & $302.7^{\mathrm{a}}$ & $299.3^{\mathrm{a}}$ & $263.0^{\mathrm{a}}$ & $203.0^{\mathrm{b}}$ & 13.66 \\
\hline Caecum, $g$ & $8.367^{\mathrm{a}}$ & $6.267^{\mathrm{b}}$ & $9.567^{\mathrm{a}}$ & $6.333^{b}$ & 0.517 \\
\hline Caecum length, $\mathrm{cm}$ & $11.50^{\mathrm{ab}}$ & $10.00^{\mathrm{b}}$ & $12.67^{\mathrm{a}}$ & $12.00^{\mathrm{a}}$ & 0.546 \\
\hline
\end{tabular}

* Dressing $(\%)=$ carcass + liver + kidney + heart (g)/ live body weight $(\mathrm{g}) * 100$

$\mathrm{a} \& \mathrm{~b}$ and $\mathrm{c}$ : means in the same row with different superscripts differ significantly $(\mathrm{P}<0.05)$.

\section{Effect of dietary treatments on meat composition:}

Results in Table (4) indicated that no significant differences among all dietary treatments on DM, Ash, EE concentrations and hence energy value of meat of growing APRI rabbits were detected. The only significant difference was with $\mathrm{CP} \%$, which rabbits fed diets (D2 and D3) containing HB (up to the level 20 and $40 \%$ ) had higher values of CP \% in the meat (72.65 and $70.51 \%$, respectively) without significant difference between them. While group fed diet containing $60 \% \mathrm{HB}$ (D4) gave the lowest significant CP value (64.7\%). Group fed control (D1) diet gave intermediate value $(67.82 \%)$ without significant difference between the latter two diets. Similar results were reported by Mohsen et al. (2015) who showed that no significant differences for chemical characteristics of meat including moisture, protein, ether extract (EE) and ash percentages of growing rabbits fed sprouted barley grains. Such variations of published data in chemical composition of rabbit's meat could be due to a lot of different resources e.g rabbits breed, stage of growth, type of feeding, physiological status, plane of nutrition, heat stress and other management and environmental conditions. Also, feeding HB diet caused improving in $\mathrm{CP}$ content and reducing $\mathrm{EE}$ content of rabbit meat, which could be more appropriate in healthy human nutrition and could be partially considered as "organic meat". 
Table 4. Effect of dietary treatments on meat composition (on, DM basis \%) of growing APRI rabbits

\begin{tabular}{|c|c|c|c|c|c|}
\hline \multirow{2}{*}{ Item } & \multicolumn{4}{|c|}{ Experimental diets } & \multirow{2}{*}{ \pm SEM } \\
\hline & D1 & D2 & D3 & D4 & \\
\hline DM & 26.14 & 25.97 & 25.42 & 23.92 & 0.94 \\
\hline Ash & 4.00 & 2.88 & 2.17 & 4.06 & 0.67 \\
\hline $\mathbf{C P}$ & $67.82^{\mathrm{bc}}$ & $72.65^{\mathrm{a}}$ & $70.51^{\mathrm{ab}}$ & $64.70^{\mathrm{c}}$ & 1.32 \\
\hline $\mathbf{E E}$ & 14.42 & 9.68 & 10.03 & 13.21 & 5.63 \\
\hline Energy Value, kJ/100g & 1679.4 & 1581.63 & 1559.1 & 1581.77 & 195.41 \\
\hline
\end{tabular}

$\mathrm{a} \& \mathrm{~b}$ and $\mathrm{c}$ : means in the same row with different superscripts differ significantly $(\mathrm{P}<0.05)$

Economic efficiency of feeding (\%) (E.E.F):

The data of effects of dietary treatments for six weeks on the net revenue feed economic efficiency (E.E.F) of APRI rabbits are presented in Table 5. Rabbits fed CFM without HB diet (D1) possessed higher total feed cost (L.E.) by about $1.19,1.17$ and 1.53 , compared with D3, D2 and D4, respectively. Accordingly, based on the pervious results the highest value of E.E.F. (\%) was observed with D1
$(139.04 \%)$ followed by D3 (66.64 \%) then D2 (64.34 $\%)$ while the lowest value was recorded with D4 $(24.95 \%)$.It seems that in spite of the lower feed cost of groups fed HB diets the return (net revenue) from the animal performance especially total meat yield did not compensate and it was insufficient to cover the cost of feeding under the condition, which the experiment was carried out.

Table 5. Effect of dietary treatments on feed economic efficiency (E.E.F) of growing APRI rabbits calculated during the experimental period

\begin{tabular}{lcccc}
\hline \multirow{2}{*}{ Item } & \multicolumn{3}{c}{ Experimental diets } \\
\cline { 2 - 5 } & D1 & D2 & D3 & D4 \\
\hline Number of survival rabbits & 10 & 10 & 10 & 9 \\
Average feed consumption (kg/rabbit) from: & & & & 1.89 \\
CFM (kg) & 4.29 & 3.01 & 2.28 & 6.174 \\
HB (kg) & 0 & 4.58 & 6.64 & $17.01(+) 55.066$ \\
Total feed consumption (Kg/rabbits) & 42.9 & $30.1(+) 45.86$ & $22.8(+) 66.42$ & 85.05 \\
Cost of CFM (L.E) & 214.5 & 150.5 & 114 & 55.066 \\
Cost of HB (L.E) & 0 & 45.86 & 66.42 & 140.116 \\
Total feed cost (L.E) & 214.5 & 196.36 & 180.42 & 0.555 \\
Av. daily body weight gain (kg) & 1.465 & 0.922 & 0.859 & 5.00 \\
Total meat yield (kg) & 14.65 & 9.22 & 8.59 & 175 \\
Selling cost (L.E) & 512.75 & 322.7 & 300.65 & 34.961 \\
Net revenue (L.E) & 298.25 & 126.34 & 120.23 & 24.95 \\
*F. E.E (6 :12 wks) & 139.04 & 64.34 & 66.64 & 17.94 \\
Relative revenue & 100 & 46.27 & 47.93 & \\
\hline The costs were 5.0, 1.0 and 35.0 L.E. of one kg concentrate, HB and one kg LBW of rabbits meat, respectively as the market \\
at time of experiment. $\quad$ *F.E.E= Net revenue/ Feed cost*100 & &
\end{tabular}

\section{CONCLUSION}

In view of the obtained results, it could be concluded that hydroponic barley fodder (HBF)can offer an alternative green fodder in diets of growing rabbits around the year, especially in semi-arid newly reclaimed lands and during summer in Egypt. It is not recommended to use it to replace more than $40 \%$ of concentrate feed mixture protein. From an economical point of view and under the conditions of this experiment, the profitability of using hydroponic barley fodder depends upon its production costs. The most expensive item is the hydroponic chambers running cost and the price of selected grains to be grown. The results showed that feeding rabbits on HB diets was associated with high protein and low fat deposition in meat which matches with the consumer's desire and health.

\section{REFERENCES}

A.O.A.C., 1990. Association of Official Agricultural Chemists. Official Methods of Analysis. Washington D.C. $11^{\text {th }} \mathrm{ed}$.

Abou Sekken, M.S.M.; Taie, H.T. and Rabie, Sh.A., 2012. Utilization of sprouted fenugreek and / or sprouted barley in rabbit feeding. Egyptian, J. Nutrition and Feeds, 15 (2): 311-321.

Anonymous, 2015. What is alfa culture or hydroponic green fodder. https://alfaculture. wordpress.com/ category /hydroponic-greenfodder/.

Ashour, G., 2001. Blood metabolites, minerals and hormones in relation to growth of rabbits. Egyptian Journal of Rabbit Science, 11(1):73-91.

Carmona, F.F.F.; Perez, C.E.P. and Pizarro, M.A.H., 2011. Productive response of rabbits fed with green hydroponic oats forage as partial 
replacement of commercial concentrate. Acta Agronmica, 60(2): 183-189.

Cheeke, P.R., 1987. Rabbit Feeding and Nutrition. Academic Press, Orlando, USA.

Duncan, D.B., 1955. Multiple Range and Multiple Ftest. Biomertrics, 11:1.

Gebremedhin, W.K.; Deasi, B.G. and Mayekar, A.J., 2015. Nutritional evaluation of hydroponically grown barley fodder. Journal of Agricultural Engineering and Food Technology, 2(2): 86-89.

Kide, W.; Desai, B and Kumar, S., 2015. Nutritional improvement and economic value of hydroponically sprouted maize fodder. Life Sciences.

Mehrez, A.Z. ;Gabr ,A.A.; EL-Ayek, M. Y. and Alla M. Gad, 2018. Effect of Partial substitution of a commercial feed crude protein by hydroponic barley fodder in diets of APRI rabbits on :1digestibility, feeding value, some blood constituents and caecum microflora count. J. Anim. and Poul. Prod., Mansoura Univ.,9 (12):453-458.

Mertin, D.; Slamecka, J.; Ondruska,L.; Zaujec, K.; Jurcik, R. and Gasparik, J., 2012. Comparison of meat quality between European brown hare and domestic rabbit. Slovak J. Animal Sci., 45 (3): 89-95.

Ministry of Agriculture (MALR), 2014. The state report of the agricultural sector in Jordan. Amman, Jordan.

Mohsen, M.K.; Abdel-Raouf, E.M.; Gaafar, H.M.A. and Yousif, A.M., 2015. Nutritional evaluation of sprouted barley grains on agricultural by-products on performance of growing New Zealand white rabbits. World Rural Observations, 7(4): 96- 107.

Morales, M.A.; Fuente B.; Juárez M. and Ávila, E., 2009. Effect of substituting hydroponic green barley forage for a commercial feed on performance of growing rabbits. World Rabbit Sci. 17: $35-38$.

Moussa, K.; Isidore, G.B.; Maxwell, B.G.A.; Clément, B.N. and Agathe, F., 2014. Effect of associated using of commercial feed supplementation and green forage on rabbit (Oryctolaguscuniculus) growth and health. Scientia Agriculturae, 6 (3): 114-119.

Naik, P.K., Dhuri, R.B. and Singh, N.P., 2011.Technology for production and feeding of hydroponics green fodder. Extension Folder No. 45/ 2011, ICAR Research Complex for Goa, Goa.

Naik, P.K., Dhuri, R.B.; Karunakaran, M.; Swain, B.K. and Singh, N.P., 2013. Hydroponics technology for green fodder production. Indian Dairyman, March Issue, Pp.54-58.

Naik, P.K.; Dhuri, R.B.; Swain, B.K. and Singh, N.P., 2012. Nutrient changes with the growth of hydroponics fodder maize. Indian J. Anim. Nutr. 29: 161-163.

NRC, 1977. Nutrients Requirements of Domestic Animals. Nutrients Requirements of Rabbits.2nd Edition. National Research Council, National Academy of Science. Washington, DC. USA.

Saidi, M.A. Abdal Rahim. and Abo Omar, J. 2015. The biological and economical feasibility of feeding barley green fodder to lactating Awassi ewes. Open J. Anim. Sci., 5, 99-105.

SAS Institute, I., 2003. SAS version 9.1.

Shanti, H.; Omar, J.; Alwaheidi, I.N.; Abdallah, J. and Dbadran, E. 2017. Effect of substituting hydroponic barley for a commercial feed on performance and blood metabolites of growing Baladi rabbits. J. New Science, 39(5): 2131-2135.

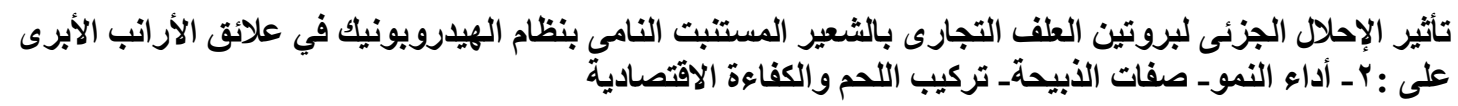

أحمد عبد الرازق جبر، أحمد زكى محرز، محمود يوسف العايق، آلاء محمد جاد

قسم الإتتاج الصيوانس، كلية الزراعة، جامعة المنصورة، مصر

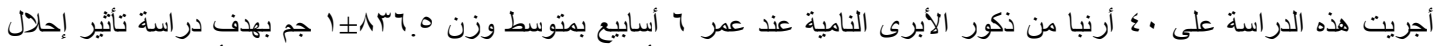

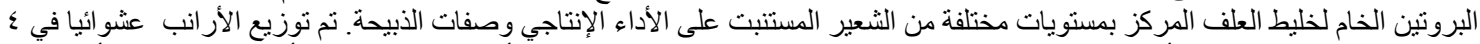

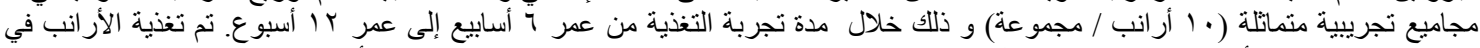

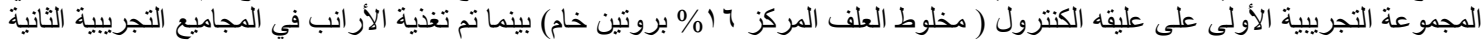

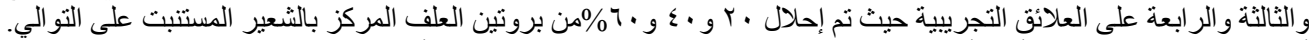

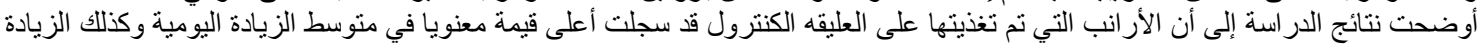

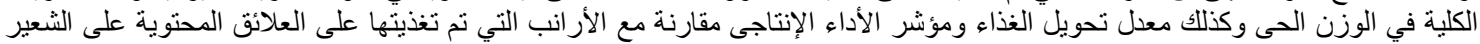

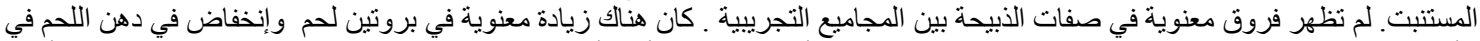

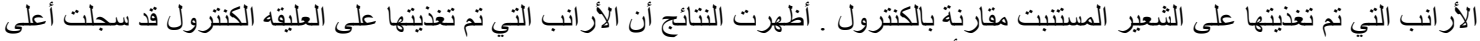
قيمة للكفاءة الاقتصادية مقارنة بالعلائق التجريبية الأخرى (الثانية و الثالثة و الرئن الرابعة).

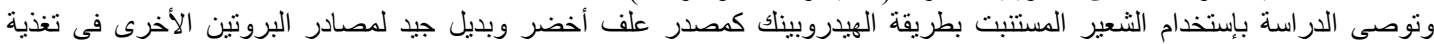

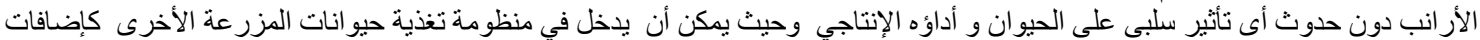
غذائية أو كعلف أخضر بديل خاصنة خلال فترة الصيف. 